\title{
APOLOGIA KRZYŻA W WYBRANYCH HOMILIACH JANA PAWŁA II
}

Pochodzące z języka greckiego słowo ,,apologia” jest definiowane jako: „1. Obrona przed zarzutami, a jednocześnie pochwała osoby, instytucji, dzieła lub idei; 2. Utwór literacki mający formę sądowej mowy obrończej”. Apologeta to „obrońca jakiejś idei, doktryny, zasady, przekonujący o jej wyższości wobec innych zasad" (Dunaj 2001). Apologizować można różne wartości, np. wolność, pracę.

Według Encyklopedii katolickiej ,,apologia religii” to w znaczeniu węższym obrona, usprawiedliwienie, uzasadnienie; w znaczeniu szerszym - uzasadnienie prawdziwości twierdzeń religijnych, motywowanie słuszności roszczeń religijnych (Kłak, kol. 786). Apologia nie jest tożsama z dyskusją, polemiką czy propagandą religijną. Apologie chrześcijaństwa są uzasadnieniem i obroną nadprzyrodzonego charakteru objawienia chrześcijańskiego. Jest to pierwotnie wykład nauki podanej przez samego Jezusa: uzasadnienie Jego godności mesjańskiej, synostwa Bożego, cudów i zmartwychwstania, spisany następnie i utrwalony w Ewangeliach. W każdej z epok historycznych (m.in. kościoła pierwotnego, średniowiecza, reformacji, oświecenia, pozytywizmu) różne aspekty doktryny wymagały obrony. Związane to było z różnymi odbiorcami (Żydzi, poganie, wyznawcy islamu), z różnymi metodami

Prof. dr hab. WŁadysŁawa BryŁa - kierownik Zakładu Historii Języka Polskiego i Dialektologii w Instytucie Filologii Polskiej UMCS; adres do korespondencji: Uniwersytet Marii Curie-Skłodowskiej, plac M. Curie-Skłodowskiej 4A, 20-031 Lublin; e-mail: wladyslawa.bryla@poczta.umcs.lublin.pl. ORCID: http://orcid.org/0000-0002-3267-6537.

Dr AgNiesZKa BryŁa-CruZ - adiunkt Katedry Językoznawstwa Angielskiego i Ogólnego w Instytucie Neofilologii UMCS; adres do korespondencji: Uniwersytet Marii Curie-Skłodowskiej, plac M. Curie-Skłodowskiej 4A, 20-031 Lublin; e-mail: agnieszka.bryla@poczta.umcs.lublin.pl. ORCID: http://orcid.org/0000-0003-3256-3185. 
badań i interpretacji Biblii, np. teoria predestynacji w okresie reformacji; racjonalizm i deizm w oświeceniu; scjentyzm i naturalizm w dobie pozytywistycznej. Od początku XX wieku zaczęto stosować pozytywny wykład wiary, co przejawiało się w apologijnych konferencjach. Był to i jest

[...] rodzaj kaznodziejstwa, podjętego w celu przeciwdziałania przejawom niewiary i ignorancji religijnej w środowiskach intelektualnych, oraz kształtowania ich chrześcijańskiego poglądu na świat [...]. Przedmiotem konferencji apologijnych są podstawowe prawdy religii chrześcijańskiej: istnienie Boga, historyczność i bóstwo Jezusa Chrystusa, nieśmiertelność duszy, sens życia, pochodzenie religii, fakt objawienia chrześcijańskiego, odkupienie, boski charakter Kościoła, ukazywanie myśli Bożej w rozwoju dziejów ludzkości. [...] Prawdy te rozważa się przede wszystkim w świetle argumentacji rozumowej, unikając zarazem jednostronnego intelektualizmu. (Pilch 791)

W okresie najbliższym św. Janowi Pawłowi II konferencje apologijne głosili m.in. księża: E. Kosibowicz, P. Bober, J. Stepa, L. Mońko.

Drugie słowo wymienione w tytule: „krzyż”, którego apologetą był św. Jan Paweł II, jest wieloznaczne. Za Encyklopedia katolicka (Gigilewicz 11) można wyróżnić następujące jego znaczenia: 1. Narzędzie służące do wykonywania kary śmierci, najbardziej hańbiącej i najcięższej; 2. Podstawowy symbol chrześcijaństwa; 3. Motyw chwały Chrystusa i wierzących; 4. Znak sprzeciwu dla niewierzących; 5. Symbol miłości Bożej i miłosierdzia Bożego; 6. Liturgiczny akt błogosławieństwa.

Św. Jan Paweł II naukę o krzyżu Chrystusa głosił bardzo intensywnie, uwzględniając te podstawowe prawdy, że krzyż Chrystusa jest znakiem odkupienia (redemptio), czyli działania Bożego przywracającego więź z Bogiem; że jest to akt najbliższej niezgłębionej milości Boga do człowieka; akt obdarowania, w którym Bóg wypowiedział naraz wszystko, i że jest tajemnicą niepojętą.

Tę prawdę o Krzyżu Chrystusa św. Jan Paweł II głosił człowiekowi XX wieku, mając świadomość, że odbiorca często egzystuje w sytuacji niewiary i traci własną podmiotowość. Na spotkaniu w auli KUL-u 9 czerwca 1987 roku przestrzegał:

Paradoksalnie można powiedzieć, że w miarę postępu wiedzy w świecie - w wymiarach makro i mikro - człowiek coraz bardziej musi na gruncie postępu cywilizacji scjentystyczno-technologicznych bronić prawdy o sobie samym. Człowiek też musi w imię prawdy o sobie samym przeciwstawić się dwojakiej pokusie: pokusie uczynienia prawdy o sobie poddaną swej wolności oraz pokusie uczynienia siebie poddanym światu rzeczy; musi się oprzeć pokusie samoubóstwienia, jak i pokusie samo urzeczowienia. (Jan Pawet II. Trzecia pielgrzymka 42)

W niniejszym szkicu, w którym spróbujemy przybliżyć sposoby głoszenia nauki o znaczeniu krzyża w dziejach narodu polskiego, w życiu społecznym i indywidualnym, wykorzystujemy teksty trzech homilii Jana Pawła II wygłoszone w Sanktuarium Krzyża Świętego w Mogile - Nowej Hucie 9 czerwca 1979 roku; w katedrze na 
Wawelu 10 czerwca 1987 roku i w Zakopanem (pod Wielką Krokwią) 6 czerwca 1997 roku.

W czasie Mszy św. odprawionej przed opactwem Cystersów w Mogile Ojciec Święty nawiązał do fizycznej obecności dwóch krzyży: historycznego krzyża - relikwii z czasów piastowskich, przywiezionego za panowania księcia Leszka Białego w 1222 roku, w czasach biskupa Iwona Odrowąża, jeszcze przed kanonizacją św. Stanisława; i drugiego krzyża, postawionego na początku lat sześćdziesiątych $\mathrm{XX}$ wieku w miejscu przyszłego kościoła, w nowo powstającej dzielnicy przemysłowej w Nowej Hucie.

W pierwszej części homilii identyfikuje się ze swoimi słuchaczami i przedstawia się jako pielgrzym.

Wspólnie pielgrzymujemy do Krzyża Pańskiego, od niego bowiem rozpoczął się nowy czas w dziejach człowieka. Jest to czas łaski, czas zbawienia. Poprzez Krzyż człowiek zobaczył na nowo perspektywę swojego losu, swego na ziemi bytowania. Zobaczył, jak bardzo go umiłował Bóg. Zobaczył i stale widzi w świetle wiary, jak wielka jest jego własna wartość. Nauczył się człowiek swoją godność mierzyć miarą tej ofiary, jaką dla jego zbawiania złożył Bóg ze swojego Syna: tak Bóg umiłował świat, że Syna swojego Jednorodzonego dał, aby każdy, kto w Niego wierzy, nie zginął, ale miał żywot wieczny (por. J 3,16). („Homilia” 238)

Jak widzimy, homileta formułuje swoją wypowiedź w formie oznajmień, o intencji deklaratywnej, której celem jest informowanie (tu chyba i przypominanie) o pewnym stanie rzeczy: chcę, żebyś wiedziat (pamiętat), że... Moc perswazyjna (przekonywania słuchaczy) wynika ze wspólnoty wiary (katolickiej), autorytetu mówcy (papież), sytuacji mówienia (podczas Mszy św.) i alegacji ${ }^{1}$ (przywołania Biblii). Jan Paweł II wypowiada tu podstawową prawdę o Krzyżu, który rozpoczyna nową jakość czasu w dziejach ludzkości, przywraca wartość i godność każdemu człowiekowi, ukazuje niezmierzoną i niepojętą miłość Boga mierzoną odkupieńczą ofiarą Jezusa. Następnie podkreśla, że obecność krzyża jest ważna, bo przypomina współczesnym prawdę „o życiu ducha ludzkiego” („Homilia” 238), o wymiarze duchowym (nie tylko materialnym) człowieka, jest znakiem obecności Ewangelii. Krzyż trwa jako znak zbawienia człowieka przez miłość Boga. W tej części homilii aktywizowana jest zarówno wiedza o znaczeniu krzyża wspólna wszystkim wierzą-

\footnotetext{
${ }^{1}$ Michał Głowiński (110) alegację definiuje następująco ,alegacjami będę przeto nazywać wszelkie odwołania tekstowe niełączące się z żywiołem dialogiczności, takie, w których cytat czy aluzja nie tylko nie staje się czynnikiem wielogłosowości, ale - przeciwnie - utwierdza jednogłosowość. Dzieje się tak wówczas, gdy przywołany tekst traktowany jest jako autorytatywny, obowiązujący a priori słuszny i wartościowy, a w konsekwencji tekst cytujący zostaje podporządkowany tekstowi cytowanemu. Pierwszy ma się stać autorytatywny za sprawą autorytatywności drugiego".
} 
cym, jak i wiedza o znaczeniu Krzyża z Mogiły jako znaku chrystianizacji Polski. Obok Krzyża historycznego ustawiono drugi, nowy drewniany.

Część drugą tej homilii, o nowym drewnianym krzyżu, kaznodzieja zapowiada następująco: „To tyle, moi drodzy o pierwszym krzyżu i najstarszym kościele. A teraz ten nowy" (239). Po tym wprowadzeniu Papież odwołuje się do osobistego wspomnienia. Tu należy przywołać wydarzenia z kwietnia 1960 roku. Otóż ówczesne władze (z Gomułką na czele) cofnęły wcześniejsze zezwolenie na budowę kościoła w Nowej Hucie i nakazały usunięcie krzyża z placu przyszłej budowy. 22 kwietnia 1960 roku ówczesny biskup krakowski - Karol Wojtyła - bezskutecznie interweniował u władz świeckich w obronie krzyża jako miejsca kultu. Kiedy 27 kwietnia 1960 roku przyjechała ekipa, która przystąpiła do demontażu krzyża, wówczas w jego obronę zaangażowali się mieszkańcy i robotnicy Nowej Huty. Rozpoczęły się zamieszki, w których kilka tysięcy robotników przeciwstawiło się przysłanym oddziałom policji i ZOMO. Władza musiała ustąpić, obroniony Krzyż pozostał na miejscu².

To wspomnienie pozwoliło Papieżowi wypowiedzieć się o godności pracy ludzkiej wynikającej z godności osoby ludzkiej, z faktu, że Chrystus, „który położył się na tym swoim krzyżu” („Homilia” 241), sprzeciwia się wszelkiej wrogiej ideologii i degradacji człowieka, w tym degradacji przez pracę. Od przywołania (choć nie wprost) fizycznej obrony krzyża, walki o budowę kościoła, rozpoczął Papież aktualizację tamtego czynu i nakreślił potrzebę i zasady współczesnej obrony Krzyża jako nowej ewangelizacji ${ }^{3}$ :

Od krzyża w Nowej Hucie zaczęła się nowa ewangelizacja: ewangelizacja drugiego milenium. Kościoły również są jej świadkiem i sprawdzianem. Wyrosły one z żywej, świadomej i odpowiedzialnej wiary - i trzeba, aby nadal jej służyły. Ewangelizacja nowego tysiąclecia musi nawiązywać do nauki Soboru Watykańskiego II. Musi być, jak uczy tenże Sobór, dziełem wspólnym biskupów, kapłanów, zakonów i świeckich: dziełem rodziców i młodzieży. („Homilia” 242)

Drugim analizowanym tekstem jest homilia wygłoszona w katedrze wawelskiej. Składa się z ośmiu numerowanych części o długości od ośmiu do dwudziestu jeden wersów, w których powtarzają się słowa: krzyż i miłość jako słowa-klucze. Aby zaprezentować specyfikę dyskursu Papieża, zacytujemy pierwszy fragment tej homilii.

\footnotetext{
${ }^{2}$ Opodal nowohuckiego krzyża powstał kościół Arka Pana, który kardynał Wojtyła konsekrował w 1997 roku. Obroniony przez robotników Krzyż-pomnik ustawiono przed Kościołem Najświętszego Serca Pana Jezusa.

${ }^{3}$ Ogłoszona w Nowej Hucie idea „nowej ewangelizacji” została podjęta przez Kościół, który realizuje ją nowymi metodami, głosząc Chrystusa ludziom nieochrzczonym w krajach misyjnych, ale też i w krajach schrystianizowanych, które uległy laicyzacji (Nowak i Przyczyna).
} 
1. Ave, Crux ${ }^{4}$

Bądź pozdrowiony, Krzyżu Chrystusa!!

Kiedy na górze w Galilei Pan mówi do Apostołów: „Dana mi jest wszelka władza w niebie i na ziemi” (Mt 28, 18), wówczas nasza myśl i serce zwraca się do Krzyża.

To w Krzyżu jest Ci dana, o Chryste, ,,wszelka władza”, taka władza, jakiej nikt inny nie ma w dziejach świata.

To w Krzyżu jest moc odkupienia człowieka, w imię której Apostołowie słyszą: Idźcie... nauczajcie wszystkie narody.

To w Krzyżu Chrystusa Bóg Trójjedyny: Ojciec, Syn i Duch Święty stał się Życiem dusz nieśmiertelnych. A początek tego Życia stanowi chrzest.

To w Krzyżu, w tym - po ludzku znaku hańby - stałeś się, o Chryste, Pasterzem naszych dusz i Panem dziejów.

Bądź pozdrowiony, Krzyżu Chrystusa!

Ave, Crux". (Jan Pawet II. Trzecia pielgrzymka 87)

Tekst homilii otwierają słowa apostrofy: „Ave, Crux. Bądź pozdrowiony, Krzyżu Chrystusa!". Jak wiadomo, apostrofa jest figurą kontaktu nacechowaną personalnością, jest bezpośrednim zwrotem do Boga (bogów), osób bądź upersonifikowanych idei czy wartości. Mówca zwraca się do adresatów innych niż ustaleni przez okoliczności mowy (tu: wiernych), odwołuje się do Krzyża i pozdrawia go. Zuzanna Topolińska (Topolińska) podkreśla: „Apel, który jest treścią vocativu, kierujemy do kogoś, kto potencjalnie jest w stanie go odebrać, więc do osoby". Następnie badaczka pisze: „Jeśli nawet - mocą konwencji stylistycznej - kierujemy ten apel do przedmiotu myśli, który w swoim inwariancie semantycznym nie ma kategorii personalności, przez sam fakt użycia frazy wokatywnej dokonujemy ad hoc kontekstowej personifikacji”. Tutaj personifikacja krzyża jest uwypuklona przez akt pozdrowienia, który zwykle kierujemy do człowieka. Jednakże to pozdrowienie uruchamia szersze myślenie o krzyżu, odsyła do osoby Jezusa ukrzyżowanego, działa na zasadzie metonimii.

Po wstępnym pozdrowieniu rozpoczyna się pozytywny wykład o znaczeniu krzyża, czyli o skutkach męki Jezusa. Katechezy papieskie są bardzo mocno osadzone w Piśmie Świętym i do ich zrozumienia niezbędna jest jego znajomość. Pierwsze zdanie: „Kiedy na górze w Galilei...” usłyszane (bądź odczytane) bez znajomości szerszego kontekstu może sprawiać wrażenie „przeskoku myślowego” i wywoływać pytanie o związek z krzyżem treści tego zdania. Otóż wydarzenia, o których mówi Papież, opisane w Ewangelii wg św. Mateusza, rozgrywają się po zmartwychwstaniu. Jak wiadomo, po śmierci Jezusa uczniowie uciekli (m.in. do Emaus), ponieważ

${ }^{4}$ Te słowa pozdrowienia Krzyża pochodzą z piątej strofy łacińskiej wersji hymnu Vexilla Regis proedunt (Sztandary Króla wznosza się) odmawianego w brewiarzowych nieszporach Wielkiego Piątku. Autorem hymnu jest św. Wenancjusz Fortunat (ok. 539-600), włoski kapłan i biskup Poitiers. Parafrazą tego hymnu jest wielkopostna pieśń Krzyżu Chrystusa bądżże pozdrowiony. 
wydawało im się, że to koniec misji Jezusa. Wówczas Jezus ukazał się niewiastom i polecił im zwołanie uczniów w Galilei:

\section{Jezus ukazuje się niewiastom.}

A oto Jezus stanął przed nimi i rzekł: «Witajcie!». One podeszły do Niego, objęły Go za nogi i oddały Mu pokłon. A Jezus rzekł do nich: «Nie bójcie się! Idźcie i oznajmijcie moim braciom: niech idą do Galilei, tam Mnie zobaczą». (Biblia Tysiąclecia, Mt 28,9-10)

Kiedy uczniowie, powiadomieni przez niewiasty, wrócili i zebrali się na górze w Galilei, wówczas ujrzeli zmartwychwstałego Jezusa, który wypowiedział słowa zacytowane przez Papieża. To w kontekście śmierci krzyżowej i zmartwychwstania Jezus mówi o swojej władzy, ,wszelkiej władzy na niebie i na ziemi”. Papież nie relacjonował sytuacji, w której Jezus przemawiał (tzn. nie podkreślał, iż było to po męce i zmartwychwstaniu). Użył tu argumentu z dixit, czyli On powiedział, tu: Jezus powiedział i odesłał „do rzeczy znanej”, do Ewangelii. Zachodzi tu dobitny sposób argumentacji, tj. topos ze świadectw, gdzie świadectwem jest Pismo Święte (w funkcji alegacji) wzmocnione autorytetem mówcy, tj. Papieża, który jest nieomylny w sprawach wiary (Korolko 71).

W tym pierwszym fragmencie homilii mówca jest piewcą Krzyża Chrystusa. Najpierw przedstawia temat syntetycznie, a następnie wypowiada cztery paralelne, anaforyczne wypowiedzenia rozpoczynające się od słów: To w Krzyżu..., mówiące o fundamentalnych skutkach śmierci Chrystusa na Krzyżu: odkupieniu, zbawieniu, życiu dusz nieśmiertelnych, początkach kościoła z Chrystusem jako „Pasterzem naszych dusz i Panem dziejów".

Te zdania mają charakter amplifikacji inwencyjnej, uwznioślającej i rozszerzającej znaczenie apostrofy otwierającej tekst. Kaznodzieja wypowiada te zdania, medytując Krzyż Chrystusa. „Medytacja nie ogranicza się do aktu rozumu i serca, ale dotyczy całego człowieka, który otwiera się na nową Rzeczywistość; w medytacji człowiek całą swą istotę zwraca na słowo Boże lub wydarzenia ewangeliczne, starając się je przyswoić i zrozumieć” (Misiurek 435). Medytacji podporządkowana jest konstrukcja tekstu z powtórzeniami struktur składniowych, które odzwierciedlają powracanie do obiektu medytacji. Powtórzenie wyraża bowiem i zarazem kształtuje postawę, która sprzyja stałemu powracaniu do wciąż tych samych spraw i znaczeń, a nie „ruchowi ku nowemu" i zmianom ${ }^{5}$. Medytacja Krzyża w obecności wiernych zgromadzonych w katedrze wawelskiej wskazuje na dwóch adresatów: pierwszym jest Bóg - właściwy adresat medytacji, drugim - człowiek, słuchacz homilii. Względem odbiorcy boskiego, wskazanego wołaczem $O$ Chryste, medytacja jest wychwalaniem dzieła zbawczego dokonanego na krzyżu, absolutnie wyjątkowego, podjętego z miłości

\footnotetext{
${ }^{5} \mathrm{O}$ typach i funkcjach powtórzeń w poezji Karola Wojtyły pisała Anna Kozłowska (228-251).
} 
Boga do człowieka. Względem odbiorcy ludzkiego (słuchających wiernych) medytacja papieska pełni funkcję ekspresywną i impresywną, wprowadza w przeżywanie tajemnicy Krzyża i ugruntowuje postawę religijną. Mówca występuje tu także w pozycji patiensa, tzn. biorcy dzieła zbawczego; utożsamia się ze swoimi słuchaczami, kiedy mówi: nasza myśl i serce zwraca się do Krzyża: stałeś się, o Chryste, Pasterzem naszych dusz. Także inicjalne i zamykające ten tekst pozdrowienie wypowiadane jest w imieniu słuchaczy. Wierni słyszą przemawiającego Ojca Świętego, przemawiającego doskonale, z rozłożonymi akcentami logicznymi, z modulacją głosu, odpowiednim dla percepcji tempem mówienia i ich wiara „rodzi się ze słuchania”.

W tym fragmencie homilii apologia krzyża ma formę pozytywnego wykładu i medytacji z odwołaniem do słów Ewangelii, a także aktu uwielbienia.

Kolejne części homilii, oznaczone cyframi 2, 3, 4 (strony 87-88), poświęcone są heroicznej wierze królowej Jadwigi, która swoją najważniejszą decyzję życiową podjęła modląc się przy krzyżu wawelskim, nazwanym przez Papieża „krzyżem Jadwigi". Podniesienie królowej do godności błogosławionej także odbyło się przy tym krzyżu, gdzie złożono jej relikwie. „Mają one sprawować tutaj jakby ciągłą, milczącą liturgię podniesienia krzyża. Podniesienie relikwii królowej Jadwigi - podniesienie przez Krzyż” - głosił Papież. Ukazując Chrystusową miłość „,do końca”, mówca przedstawia wyjątkową sytuację, w której znalazła się Jadwiga, od której Bóg też zażądał „miłości do końca”: „Bóg cię postawił pośrodku ludów i narodów. Powołał cię, abyś ogarnęła swym sercem ich losy, ich dążenia, ich zmagania. Abyś odgadła Boże zamiary w stosunku do Polski, do Litwy, do ziem ruskich". Następnie mówca stosuje zamianę czasu z przeszłego na teraźniejszy i wykorzystując retoryczną figurę hipotypozy (obrazowe przedstawienie zdarzeń), ,eksponuje rzeczy w takiej formie, że sprawa zdaje się rozgrywać, a rzecz toczyć, bezpośrednio na naszych oczach" (Perelman 53). Zadaje dramatyczne pytania:

Na Krzyżu Chrystus „oddał za nas życie swoje” (1 J 3,16). Czy ty także, młoda królowo Polski, Andegawenko, nie powinnaś „oddać życia za braci?”

kochała przecież ludzką miłością Wilhelma i miała prawo do tej ludzkiej, pięknej miłości, żywionej od dziecka [...] która mogła stać się przecież jej życiową drogą i powołaniem.

Drugie pytanie brzmi równie dramatyczne:

Ale „,zy ty także nie powinnaś «oddać» swojej miłości za tę Miłość?” Jak może w tobie „trwać miłość do Boga” (por. 1 J 3,17), gdybyś zamknęła twoje serce do samej tylko „ludzkiej miłości?”

Po tych dwu pytaniach następują trzy kolejne:

Co ci mówi ten Chrystus z wysokości wawelskiego Krzyża? Przedziwna jest jego „władza” nad sercem człowieka. 
Skąd się bierze ta władza?

Jaką ma moc On, wyniszczony, skazany na swoja krzyżową agonię na tylu miejscach świata? (Jan Pawet II. Trzecia pielgrzymka 88)

Te zadane Jadwidze pytania, mające formę pytań deliberatywnych (medytatywnych), wymagają odpowiedzi koncepcyjnej związanej z aktywnością intelektualną, służą też do emocjonalizacji odbioru i do stymulowania postawy słuchaczy, gdyż to oni byli rzeczywistymi adresatami pytań.

Anna Pajdzińska, analizując perswazyjność w tekstach św. Jana Pawła II stwierdziła, że „mówca przewiduje wątpliwości i rozterki słuchaczy, jest świadom możliwości różnych wyborów i stara się wskazać przesłanki przemawiające za tym właściwym. Tak zbudowany tekst w niczym nie przypomina nakazu z pozycji najwyższej władzy, a zwykle jest od niego skuteczniejszy" (157). Papież ukazał dylematy Jadwigi, a wybór którego dokonała, jest dowodem jej heroizmu. Sylwetka królowej jest argumentem, że nawet bardzo trudne wybory są możliwe i że właśnie one prowadzą do świętości. Przykład postawy Jadwigi jest ponadczasowy, zawsze aktualny.

\begin{abstract}
„My wiemy, że przeszliśmy ze śmierci do życia, bo miłujemy braci, kto...nie miłuje, trwa w śmierci" (1 J 3,14). Tak. Wiemy. Wiedziała o tym nasza królowa Jadwiga, błogosławiona i wiedzę tę ugruntowała w dziejach narodu. W dziejach dusz polskich. Taka była zawsze - i taką pozostała wymowa wawelskiego krzyża. I taka jest wymowa każdego krzyża na ziemi. Każdego krucyfiksu. (Jan Pawet II. Trzecia pielgrzymka 90)
\end{abstract}

Krzyż Jadwigi cieszy się wielkim kultem i czcią. Papież wspomina modlących się przy nim św. Kazimierza królewicza, zakonnika Michała Giedrojcia i ks. infułata Kazimierza Figlewicza, których nazywa miłośnikami wawelskiego krucyfiksu Jadwigi.

Homilię zamykają dwa rozbudowane wypowiedzenia będące rozwinięciem apostrofy inicjalnej i podsumowaniem dotychczasowych rozważań:

Bądź pozdrowiony, Krzyżu, gdziekolwiek się najdziesz, na polach, przy drogach, na miejscach gdzie ludzie cierpią i konają... na miejscach, gdzie pracują, kształcą się i tworzą...

Na każdym miejscu, na piersi każdego człowieka, mężczyzny czy kobiety, chłopca czy dziewczyny... i w każdym ludzkim sercu, tak jak w sercu Jadwigi, pani wawelskiej.

Bądź pozdrowiony, Krzyżu Chrystusa!

Ave, Crux! (90)

Powyższe wypowiedzenia są apelem o nieograniczoną cześć dla krzyża. Inicjalna forma życząca połączona została z uogólnieniem wyrażonym przysłówkiem gdziekolwiek i przymiotnikiem każdy. Przysłówek upowszechniający gdziekolwiek wskazuje na nieokreśloność miejsca, którego dokładne wskazanie jest dla mówiącego nieistotne (chodzi o każde miejsce) i dlatego uzupełnia go próba wyliczenia, 
z przerwami w wypowiedzi (sygnalizowanymi w druku trzema kropkami). Mówca posłużył się tu retoryczną figurą myśli, zwaną reticentia, która polega na przerwaniu wypowiedzi w środku mowy, gdy resztę sądu (myśli) pozostawia się słuchaczowi. Z kolei przymiotnik każdy (w znaczeniu: wszelki, bez wyjątku) jest kwantyfikatorem ogólnym i orzeka o jakiejś własności wszystkich przedmiotów. Skoro Papież mówi o każdym miejscu, każdym człowieku, każdym mężczyźnie, kobiecie, chłopcu, dziewczynie, każdym ludzkim sercu, to odbiorca tej wypowiedzi musi się poczuć włączony do grona czcicieli krzyża, powinien odczuć potrzebę aktywizacji i działania na wzór Jadwigi. Trzykrotnie powtarzany przymiotnik każdy wzmacnia też ekspresję tej wypowiedzi, ułatwia percepcję i pełni funkcję mnemotechniczną.

Kolejną, powszechnie znaną homilię o krzyżu św. Jan Paweł II wygłosił dziesięć lat później: 6 czerwca 1997 roku w Zakopanem, „u stóp krzyża na Giewoncie” jak sam nazwał to miejsce - w stulecie ustawienia tam krzyża przez mieszkańców Podhala. Homilia w Zakopanem została wygłoszona w uroczystość Najświętszego Serca Pana Jezusa i do tego aspektu ofiary krzyżowej nawiązuje Papież mówiąc:

„Będą patrzeć na Tego, którego przebili” (J 19,37). Oto słowa, które usłyszeliśmy w dzisiejszej
Ewangelii. Św. Jan tym proroczym cytatem kończy swój opis męki i śmierci Chrystusa na krzyżu.
Wiemy z tego opisu, że w Wielki Piątek przed świętem Paschy Żydzi prosili Piłata, aby wszyst-
kim trzem ukrzyżowanym połamano golenie i usunięto ich ciała (por. J 19,31). Tak też żołnierze
uczynili w stosunku do obu złoczyńców ukrzyżowanych z Jezusem. „Gdy [zaś] podeszli do Jezusa
i zobaczyli, że już umarł, nie łamali Mu goleni, tylko jeden z żołnierzy włócznią otworzył Mu
bok i natychmiast wypłynęła krew i woda” (J 19,33-34). Był to dowód śmierci. Żołnierze mo-
gli zapewnić Piłata, że Jezus z Nazaretu zakończył życie. Natomiast św. Jan Ewangelista w tym
miejscu widzi potrzebę jakby szczególnego uwiarygodnienia. Pisze tak: „Zaświadczył to ten, który
widział, a świadectwo jego jest prawdziwe”. I równocześnie stwierdza, że w tym przebiciu Chry-
stusowego boku wypełniło się Pismo, które mówi: „Kości jego łamać nie będziecie,” a na innym
miejscu: „Będą patrzeć na Tego, którego przebili” (por. J 19,35-37). To właśnie ten ewangeliczny
zapis stoi u podstaw całej tradycji kultu Serca Bożego [...]. Te słowa kierują nasz wzrok ku krzyżo-
wi świętemu, ku drzewu krzyża, na którym zawisło zbawienie świata. (Jan Paweł II w Polsce 133)

W powyższym tekście Papież zastosował niemalże formę wykladu nauki o krzyżu z monologową, pierwszoosobową formą wypowiedzi o charakterze informacyjno-komentującym, następnie zastosował argumentację ze świadectwa. Podkreślił szczególne świadectwo słowa św. Jana Ewangelisty, ale ukazał też świadectwo życia innych wyznawców. Zaprezentował sylwetki dwu kobiet: Bernardyny Marii Jabłońskiej, współpracownicy brata Alberta Chmielowskiego, i Marii Karłowskiej - założycielki Zgromadzenia Sióstr Pasterek, które zawsze były wierne Bogu i z miłości do Niego służyły ubogim i potrzebującym. Po scharakteryzowaniu Bernardyny Marii Jabłońskiej zauważył: „I dobrze, że jest beatyfikowana w Zakopanem, bo to jest zakopiańska święta. Chociaż nie pochodzi stąd, ale tu się rozwinęła duchowo do świętości, przez Kalatówki, poprzez pustelnię Brata Alberta" (Jan Pawet II w Polsce 135). 
Z kolei o Marii Karłowskiej powiedział: „Dobrze, że i ona beatyfikowana jest w Zakopanem, bo ten krzyż z Giewontu patrzy na całą Polskę, patrzy i na północ, na Pomorze, na Płock". Beatyfikowane dwie zakonnice są - zdaniem Papieża - wzorem do naśladowania i świadkami miłości Ukrzyżowanego.

Jednakże obecność i trwanie krzyża na Giewoncie nie są ważne tylko dla górali, mieszkańców Podhala. W tym kazaniu Papież kolejny raz uświadamia swoim słuchaczom, że nauka płynąca z krzyża nie dezaktualizuje się i nie ma granic terytorialnych.

Ten krzyż [ze szczytu Giewontu] stoi tam i trwa. Jest niemym, ale wymownym świadkiem naszych czasów. Rzec można, iż ten jubileuszowy krzyż patrzy w stronę Zakopanego i Krakowa, i dalej: w kierunku Warszawy i Gdańska. Ogarnia całą naszą ziemię od Tatr po Bałtyk. Chcieli wasi ojcowie, aby Chrystusowy krzyż królował w sposób szczególny na Giewoncie. I tak też się stało. (Jan Pawet II w Polsce 134)

Następnie kaznodzieja zmienia styl i funkcję wypowiedzi, wykład zamienia na wypowiedź nakazowo-życzącą i apeluje o wierność krzyżowi Chrystusa.

Umiłowani bracia i siostry, nie wstydźcie się krzyża. Starajcie się na co dzień podejmować krzyż i odpowiadać na miłość Chrystusa. Brońcie krzyża, nie pozwólcie, aby Imię Boże było obrażane w waszych sercach, w życiu społecznym czy rodzinnym. Dziękujmy Bożej Opatrzności za to, że krzyż powrócił do szkół, urzędów publicznych, szpitali. Niech on tam pozostanie! Niech przypomina o naszej chrześcijańskiej godności i narodowej tożsamości, o tym, kim jesteśmy i dokąd zmierzamy, i gdzie są nasze korzenie. Niech przypomina nam o miłości Boga do człowieka, która w krzyżu znalazła swój najgłębszy wyraz [wyróżnienia graficzne - WB i AB-C]. (134)

Apelatywność wyrażona jest formami rozkaźnika, które kategorycznie nakazują odbiorcy konieczność działania, o intencji: (jeśli tego nie zrobisz, będzie źle), stawiając odbiorcę w stan zobowiązania. Mówca zastosował tu strategię przekazywania inicjatywy. Nie tylko Ewangeliści, święci, osoby beatyfikowane czy papież powinni być wierni krzyżowi. To Polacy, spadkobiercy ojców, którzy ustawili krzyż na Giewoncie, mają bronić krzyża, który powrócił do różnych sfer życia publicznego. W postawie wdzięczności za to, mają trwać w poczuciu godności chrześcijańskiej i narodowej. Z kolei tryb życzący, złożony z partykuły niech i czasownika w trzeciej osobie liczby pojedynczej (niech pozostanie, niech przypomina) wyraża życzenie, a właściwie pragnienie nadawcy tekstu, aby zaszedł wymieniony stan rzeczy, i przekonanie, że odbiorca jest w stanie tego dokonać. Mówca jest przeświadczony, że to co proponuje i zaleca, o co apeluje, jest dobre dla wszystkich. Te słowa o szacunku dla krzyża i jego oddziaływaniu stały się ponadczasowym przesłaniem dla Polaków.

Apologia Krzyża głoszona przez św. Jana Pawła II polega na:

1) objaśnianiu znaczenia męki krzyżowej Jezusa Chrystusa w świetle Ewangelii;

2) prezentowaniu przykładów osób wiernych krzyżowi przez jego wyznawanie i przyjmowanie cierpienia (m.in. królowej Jadwigi, św. Stanisława, św. Ka- 
zimierza, ks. infułata Kazimierza Figlewicza, który był kustoszem w katedrze wawelskiej w czasie II wojny światowej, kiedy studiował Karol Wojtyła i uczestniczył w nabożeństwach w tej katedrze; Marii Karłowskiej, Alberta Chmielowskiego, Bernardyny Jabłońskiej).

3) aktualizowaniu Ewangelii, nauki o krzyżu, w różnych wydarzeniach historycznych narodu (m. in. czasach komunizmu, stanu wojennego, powstania „Solidarności”);

4) stosowaniu różnych językowo (i retorycznie) sposobów mówienia o krzyżu: wykład, uwielbienie, medytacja, dyrektywa, życzenie i wiele innych.

O krzyżu św. Jan Paweł II mówił niezliczoną ilość razy. Także on sam z najwyższego Pasterza Kościoła przemieniał się stopniowo w żywy symbol ludzkiego cierpienia, w ikonę Chrystusa na krzyżu, co przejmująco uwidocznił swoim przylgnięciem do krzyża w ostatni Wielki Piątek swojego życia.

\section{BIBLIOGRAFIA}

Biblia Tysiąclecia, Pismo Święte Starego i Nowego Testamentu. Pallottinum 2019.

Dunaj, Bogusław. Stownik współczesnego języka polskiego, t. 1, Przegląd Readers Digest, 2001.

Gigilewicz, Edward. „Krzyż”. Encyklopedia katolicka. Towarzystwo Naukowe KUL, t. X, 2004, kol. 11. Głowiński, Michał. Poetyka i okolice. Wydawnictwo Naukowe PWN, 1992.

Jan Pawet II. Trzecia pielgrzymka do Polski. Przemówienia i homilie. 9 VII 1987-14 VI 1987. Znak, 1987.

Jan Pawet II w Polsce: 31 maja 1997 - 10 czerwca 1997: przemówienia i homilie. Znak, 1997.

Jan Paweł II. „Homilia w czasie Mszy świętej odprawionej przed opactwem OO. Cystersów w Mogile”.

Gaude Mater Polonia. Pierwsza pielgrzymka, czerwiec 1979, red. Andrzej Sujka, Wydawnictwo M, 2010, ss. 237-243.

Kłak, Tadeusz. „Apologia religii”. Encyklopedia katolicka. Towarzystwo Naukowe KUL, t. I, 1998, kol. 786.

Korolko, Mirosław. Sztuka retoryki. Przewodnik encyklopedyczny, Wydawnictwo Wiedza Powszechna, 1998.

Kozłowska, Anna. Od psalmów słowiańskich do rzymskich medytacji. O stylu artystycznym Karola Wojtyły. Wydawnictwo Uniwersytetu Kardynała Wyszyńskiego, 2013.

Misiurek, Jerzy. „Medytacja”. Encyklopedia katolicka. Towarzystwo Naukowe KUL, t. XII, 2008 , kol. 435.

Nowak, Małgorzata, Wiesław Przyczyna. Nowa ewangelizacja. Język-teologia-kultura. Biblos, 2017. Pajdzińska, Anna. „O perswazyjności w tekstach Jana Pawła II”. Jan Pawet II Odnowiciel Mowy Polskiej, red. Stanisław Mikołajczuk, Magdalena Wrześniewska-Pietrzak, Wydawnictwo UAM, 2009.

Perelman, Chaim. Imperium retoryki. Wydawnictwo Naukowe PWN, 2002.

Pilch, Zygmunt. „Apologijne konferencje”. Encyklopedia katolicka. Towarzystwo Naukowe KUL, t. I, 1998, kol. 791.

Topolińska, Zuzanna. „Vocativus - kategoria gramatyczna”. Otázky slovanské syntaxe, Univerzita J. E. Purkyne, 1973, ss. 269-273. 


\section{APOLOGIA KRZYŻA \\ W WYBRANYCH HOMILIACH JANA PAWŁA II}

Streszczenie

W niniejszym artykule przeanalizowano sposoby obrony Krzyża w trzech homiliach Jana Pawła II wygłoszonych w Polsce: w Nowej Hucie, w Katedrze na Wawelu i w Zakopanem. Zaobserwowano, że Papież stosuje argumentację ewangeliczną i historyczną. Podkreśla znaczenie Krzyża jako boskiego znaku odkupienia, obdarowania i miłości Jezusa Chrystusa do człowieka. Wymienia także osoby, które dochowały wierności Krzyżowi i swoim heroizmem zapisały się w historii Polski: królowa Jadwiga, brat Albert Chmielowski, Bernardyna Jabłońska, Maria Karłowska. W homilii wygłoszonej w Nowej Hucie Papież nakreślił program nowej ewangelizacji, polegającej na wytrwałej i odważnej obronie Krzyża w każdym miejscu i czasie, będącej powinnością wszystkich wierzących. W tekście zwrócono również uwagę na aspekty retoryczne przemówień papieskich: zróżnicowane akty mowy (wykład, medytacja, apel) i środki stylistyczne (m.in. powtórzenia, paralelizmy, pytania retoryczne).

Słowa kluczowe: homilia; Jan Paweł II; krzyż; obrona; nowa ewangelizacja

\section{THE APOLOGIA OF THE CROSS IN SELECTED HOMILIES OF JOHN PAUL II}

\section{Sum mary}

This paper presents an analysis of the various ways the Cross was defended in John Paul II's homilies delievered in Poland on the following occasions: in Nowa Huta, in the Wawel Royal Cathedral and Zakopane. The speaker used arguments anchored in the Gospel and history. He emphasised the meaning of the Cross as a sign of God's redemption, gift and love towards humans. The speaker evoked people from Polish history who remained faithful to the Cross and are remembered for their heroic attitude: Queen Jadwiga, brother Albert Chmielowski, Bernardyna Jabłońska and Maria Karłowska. In his homily given in Nowa Huta, the Pope signalled the idea of new evangelisation, which requires all believers to undertake persistent and courageous defence of the Cross, irrespective of time and place. The paper also discusses rhethorical aspects of the sermons, such as various types of speech deployed therein (lectures, meditations, appeals) and stylistic devices (e.g. similes, parallelisms, rhetorical questions).

Keywords: homily; John Paul II; Cross; defence; new evangelisation 